\title{
Present Scenario of Renewable and Non-Renewable Resources in Bangladesh: A Compact Analysis
}

\section{Md Niaz Murshed Chowdhury*}

Graduate Research Assistant, Department of Economics, South Dakota State University, Brookings, SD USA

*Corresponding author: Md Niaz Murshed Chowdhury, Graduate Research Assistant, Department of Economics, South Dakota State University, Brookings, SD USA, Tel: + 6056519045; E-mail: niaz060707@gmail.com

Received date: December 05, 2014, Accepted date: January 21, 2015, Published date: January 30, 2015

Copyright: (c) 2015 Chowdhury MNM. This is an open-access article distributed under the terms of the Creative Commons Attribution License, which permits unrestricted use, distribution, and reproduction in any medium, provided the original author and source are credited.

\begin{abstract}
This research deliberately searches the present scenario of renewable and non-renewable resources in Bangladesh and also focuses on their effective management. Therefore, the research is unique in terms of focusing the present scenario of natural resources and the research highlights the present conditions of natural resources. Most of the study and research on NRs focus on superficial problems, poverty, gender, and scientific measure of resource degradation. This research gives special attention to find the present scenario and to find the actors who are responsible for NRs management. There are considerable opportunities of Bangladesh to boost the economic growth through renewable and nonrenewable resource. With the help of these resources Bangladesh can generate electricity and can meet the required demand in the future. Therefore, the Government and the Private sector should work hand to hand to emphasize more renewable energy sources to produce electricity to solve our power crisis problem. Renewable energy sources discussed above can help Bangladesh to produce more power in order to reduce Load-shedding problem. Time has come to look forward and work with these renewable energy fields to produce electricity rather than depending wholly on conventional method. In addition, we observed that Bangladesh has a huge amount of natural Gas and other mineral resources. Proper and corruption free management can be able to solve the problem of energy crisis.
\end{abstract}

Keywords: Natural resource; Renewable; Non-renewable; Public and private sector; NR management

\section{Introduction}

Natural resources and their management are the most important for a country. There are many states which are straightly depends on natural resources. Bangladesh is a developing and a probabilities country, with small area. We have also some natural resources, some are renewable and some are nonrenewable. Renewable resources are natural resources that can be replenished in a short period of time. On the other hand, non-renewable resource is a natural that cannot be remade or re-grown at a scale of comparable to its consumption. In Bangladesh, there are many natural resources such as: renewable natural resources are Energy, Water, Fish, Forest etc. and Coal, petroleum, oil, natural gas Rock, Sand etc. are considered nonrenewable natural resources. Energy is the prime ingredient for sustainable economic development of a country. Economic Development depends on effective management of one's natural resources. People all over the world have a large unsatisfied demand of energy, which is growing rapidly in the span of time. Bangladesh has a massive potential for renewable energy and the natural availability of alternative energy that creates opportunities of Growth in Bangladesh. Technologies should be developed to produce energy in an environment friendly manner as well as enough importance should be given to conserve the energy in most efficient shape. In order to ensure energy security, the primary energy source of the country especially gas, coal and other mineral resources have been taken into consideration.
Majority rural poor of Bangladesh depend on Natural Resources (NR) for their livelihoods. Land, water, forests, and live stocks are the sources of livelihoods. The rural economy depends on productivity of the natural resources. Small trade and manufacturing process cannot replace dependency over agricultural and natural resources. The country lacks institutional framework in terms of Natural Resource Management (NRM), which has resulted chaos and conflict over NRs and eventually poor and marginal people do not have access to. People have been losing their entitlement to these resources. On the hand, degradation of land and other resources along with bio-diversity and eco-system are the prime concern for the entire population in Bangladesh. Bangladesh is experiencing an acute shortage of electric power that is likely to be worsening day by day that stresses the need for the deployment of renewable energy resources to extenuate this energy crisis. In Bangladesh, there are many natural resources such as coal, gas, petrol. The main source of energy in Bangladesh is Natural gas (24\%) that is likely to be depleted by the year 2020. Then Bangladeshis people will be faced a problem. In this case renewable energy helps the people of Bangladesh. Bangladesh has a vast potential for renewable energy and the natural availability of alternative energy creates opportunities of Growth in power sector; the substantial availability of renewable energy sources in the form of solar, biomass, biogas, hydropower and wind energy can provide opportunities of sustainable energy based development. Bangladesh is one of the low energy consuming countries of the world. The national grid could so far cover only $35 \%$ of the total population, and only 3 per cent people are enjoying piped gas supply. About 72 per cent people of Bangladesh live in rural areas, where the situation is worse and renewable energy is considered to be the right choice for providing clean energy to these remote settlements. Bangladesh is endowed with rich and extensive fisheries resources. Due to natural conditions and geographical 
location, Bangladesh has huge fisheries resources having high potential of increasing fisheries production. The country's fisheries may be conveniently divided into inland and marine sectors, although the dividing line between salt and fresh water, and open sea and inland waterway is very nebulous. Fishermen to move seasonally from inland open waters to sea fishing so that any demarcation between the two fisheries must be arbitrary. Inland fisheries is further divided into two groups i.e. aquaculture and inland capture. An inland fishery occupies an area of 4.575 million ha and marine capture covers $1,66,000$ sq. km. The culture fisheries include ponds, ox-bow lakes and coastal shrimp farms. The flood plains and the beels, which cover an area of 29.5 lakh ha, offering tremendous scope and potential for augmenting fish production by the adopting aquaculture based enhancement techniques.

The objectives of this research are:

- To have an overview on natural resources: data and information about land, water, forest, minerals and fisheries could help to produce the overview.

- To determine calamitous factors involved changing bio-diversity and destruction of ecology.

- Figure out the leakage of natural resource management and suggest the appropriate policy laws.

\section{Data and Methodology}

The research has studied secondary data and information. This research carefully examines some existing reports and study on natural resources in Bangladesh. The literature review also includes policy papers, declaration, and conventions on natural resources, biodiversity, and ecology. Information, data, and case studies are studied and compiled. Both Bengali and English daily newspapers are studied for seeking information and data. The daily newspapers selected for this purpose are The Somokal, The New Age, The Financial express, The Independent, and The Daily Star. Information and data on natural resources are collected, compiled and analyzed for this research. Internet sources include research paper, reports, workshop outputs and information published in the web sites [1-5].

This research deliberately searches the present scenario of renewable and non-renewable resources in Bangladesh and also focuses on their effective management. Very few researches are available to focus on both things. Therefore, the research is unique in terms of focusing the present scenario of natural resources and the research highlights the present conditions of natural resources. Most of the study and research on NRs focus on superficial problems, poverty, gender, and scientific measure of resource degradation. This research gives special attention to find the present scenario and to find the actors who are responsible for NRs management.

\section{An Overview of Renewable (Energy, Fish, Forest, Land, Water) Resources of Bangladesh}

\section{Energy situation}

Present scenario of electricity production: Bangladesh, with its 160 million people in a land mass of 147,570 sq. $\mathrm{km}$ is an emerging economy of South Asia successfully maintaining sustained economic growth of least $6 \%$ since last decade resulted a considerable high electricity demand each year. A booming economic growth, rapid urbanization and increased industrialization and development have increased the country's demand for electricity. Presently, $62 \%$ of the total population (including renewable energy) has access to electricity and per capita generation is $321 \mathrm{kWH}$, which is very low compared to other developing countries. In Bangladesh, renewable energy is considered to be the right choice for providing clean energy to these remote settlements. Power generation in Bangladesh was mono-fuel dependent, i.e. indigenous natural gas since 2009 considering its apparent huge availability. About $89 \%$ of generated power comes from natural gas and the rest is from liquid fuel, coal and hydropower. The present share of renewable energy is only $0.5 \%$. As per election manifesto of the present government electricity generation in the country would be 7000 MW by the year 2013, 8000 MW by 2015 and $20,000 \mathrm{MW}$ by the year 2021. The government aims to generate additional 15,000 MW electricity, within 2016 under short, medium and long term plan. The government has further extended its vision targeting the upcoming years up to 2030 and prepared the Power System Master Plan 2010 (PSMP). This plan states that in 2030 the demand of power would be around 34,000 MW while the generation capacity would be about 39,000 MW. Presently, the generation capacity is nearly 9,713 MW (September 2013) which implies that much endeavor is required to achieve the goal [6-10].

\section{Overview in different renewable energy sources}

Solar power: Solar Energy can be a great source for solving power crisis in Bangladesh. Bangladesh is a south Asian country located in between latitude $20^{\circ} 34^{\prime}$ and $26^{\circ} 39^{\prime}$ north and longitude $80^{\circ} 00^{\prime}$ and $90^{\circ} 41^{\prime}$ east that is an ideal location for solar energy utilization. Bangladesh is a subtropical country, $70 \%$ of year sunlight is dropped in Bangladesh. For this reason, we can use solar panels to produce electricity largely. Solar radiation varies from season to season in this country and receives an average daily solar radiation of $4-6.5 \mathrm{kWh} / \mathrm{m}^{2}$. In a recent study conducted by Renewable Energy Research Centre, it is found maximum amounts of radiation are available in the month of March-April and minimum in December-January.

The vision is targeted to achieve through a concerted effort of Bangladesh Government involving a number of government ministries and their affiliated agencies. In addition, there would be a strong involvement of private sector (more than 50\%) in the project implementation.

Under this initiative there would be two types of projects:

- Business type involving contribution from beneficiaries and private sector management.

- Social Service type aiming to implement government's social commitment.

The snapshot of the program is as follows: Investments projects are 1. Installation of solar irrigation pumps. 2. Installation of mini grid solar system. 3. Solar park. 4. Roof-top solar power solution. Social sector projects are 1. Solar electrification at railway station. 2. Solar electrification at Union Information Services Centers. 3. Solar led street lighting. 4. Solar electrification in rural health center. 5. Installation of Solar Home System in Religious Establishments. 6. Solar Electrification in Remote Education Centers. 7. Installation of Solar Home System in Government / Semi-government offices.

Biogas: Organic wastes such as dead plant and animal material. Animal dung, and Kitchen waste can be converted into a gaseous fuel called biogas. Biogas originates from biogenic material and is a type of 
biofuel. Major components of biogas are 40-70\% methane $\left(\mathrm{CH}_{4}\right)$ $30-60 \%$ carbon dioxide $\left(\mathrm{CO}_{2}\right)$ and other gases (1-5\%). It also contains several trace gases like Hydrogen sulfide $\left(\mathrm{H}_{2} \mathrm{~S}\right)$, Nitrogen $\left(\mathrm{N}_{2}\right)$, Ammonia $\left(\mathrm{NH}_{3}\right)$ and Carbon monoxide (CO). A biogas based electricity generation system consists of a digester, a biogas collection tank, a generator as well as the piping and controls required for successful operation. The biogas is produced in the anaerobic digester, where anaerobic fermentation takes place which is provided every day with livestock manure in the form of cattle dung. Biogas production plays an important role in Bangladesh since the necessary resources are plentiful. The Government along with several NGOs are working together for development of power production from Biogas. Grameen Shakti is one of the most uttered NGO in field of biogas and has completed several works. They have completed 13,500 biogas plants. Recently Seed Bangla Foundation has proposed a $25 \mathrm{KW}$ Biogas based Power plant in Rajshahi. IDCOL A Government owned Investment Company fixed a target to set up 37,669 biogas plants in Bangladesh by 2012, under its National Domestic Biogas and Manure Programmers (NDBMP). Bangladesh has a wonderful climate for biogas production. The ideal temperature for biogas is around $35^{\circ} \mathrm{C}$. The temperature in Bangladesh usually varies from $6^{\circ} \mathrm{C}$ to $40^{\circ} \mathrm{C}$. But the inside temperature of a biogas digester remains at $22^{\circ} \mathrm{C}-30^{\circ} \mathrm{C}$, which is very near to the optimum requirement.

Biogas based electricity generation plants: IDCOL is financing setting up of three biogas based on electricity generation plants, one in Mymensingh and two in Gazipur, and one organic fertilizer plant in Gazipur by Paragon Agro Ltd. Electricity generated from these plants will be supplied to the adjacent poultry farms of Paragon Poultry Ltd. (PPL) at BDT $4 / \mathrm{kWh}$, while organic fertilizer will be sold in the market at BDT 15 per $1 \mathrm{Kg}$ packet and BDT 400 per $40 \mathrm{Kg}$ packet. Total project cost is BDT 149.40 million.

National domestic biogas and manure program: Infrastructure Development Company Limited (IDCOL) is implementing National Domestic Biogas and Manure Programme (NDBMP) with support from GoB, SNV- Netherlands Development Organization. Under the project a total of 37,269 domestic sized biogas plants have been financed during the period 2006-2012. The overall objective of the NDBMP is to further develop and disseminate domestic biogas plants in rural areas with the ultimate goal to establish a sustainable and commercial biogas sector in Bangladesh.

Wind: Bangladesh is in the midst of a severe energy and power supply crisis; one of the worst in South Asia. However, the government is now looking to explore the potential of wind energy, particularly along the country's $724 \mathrm{~km}$ long coastline. Wind energy can potentially generate more than 2000 -MW of electricity in the coastal regions. The growth of wind energy in the underdeveloped, coastal areas of the country holds hope for poor, isolated communities that are not connected to the national electricity grid and who are also unlikely to receive grid connection in the near future due to the high cost of establishing infrastructure and growing scarcity of traditional energy inputs. The Bangladesh Power Development Board has estimated that wind energy can contribute to $10 \%$ of the energy needs of the country. The Board has also calculated the cost to generate one kWh from wind energy to be about half the cost of generating an equivalent unit of power from solar energy. The expansion of the potential of wind energy will be crucial in order for Bangladesh to achieve its national vision of providing electricity to all of its population by 2020 .

Biomass: Bangladesh is an agricultural country and has strong potential for biomass gasification based on electricity. Cattle dung, agricultural residue, poultry dropping, water hyacinth, rice husk etc. used for biomass power generation are available in Bangladesh. More common biomass resources available in the country are rice husk, crop residue, wood, jute stick, animal waste, municipal waste, sugarcane bagasse etc. Exploration of these resources for electricity generation is still at preliminary stage.

Micro Hydro: The Karnafuly Hydro Power Station is the only hydropower plant in the country with a capacity of $230 \mathrm{MW}$. It is operated by BPDB (Bangladesh Power Development Board). BPDB is considering increasing production up to $330 \mathrm{MW}$. Micro hydro and mini hydro have limited potential in Bangladesh with exception of Chittagong Hill Tracts. Hydropower assessments have identified some possible sites from $10 \mathrm{~kW}$ to $5 \mathrm{MW}$ implementation of which is still at large. Other renewable energy sources include bio-fuels, gasohol, geothermal, river current, wave and tidal energy. Potentialities of these resources are yet to be explored as shown in the Table 1 [11-15].

\begin{tabular}{|l|l|l|}
\hline Resources & Potential & Entities Involved \\
\hline Solar & Enormous & $\begin{array}{l}\text { Public and Private } \\
\text { sector }\end{array}$ \\
\hline Wind & Resource mapping required & Public sector / PPP \\
\hline Hydro & $\begin{array}{l}\text { Limited potential for micro or } \\
\text { mini hydro max. (5 MW).Est. } \\
\text { hydro potential: approx. 500 } \\
\text { MW }\end{array}$ & Mainly public entities \\
\hline $\begin{array}{l}\text { Domestic Biogas System } \\
\text { Biomass Husk based } \\
\text { Power Plant gasication }\end{array}$ & $\begin{array}{l}8.6 \text { Million Cubic Meter of } \\
\text { Biogas }\end{array}$ & $\begin{array}{l}\text { Public and Private } \\
\text { sector }\end{array}$ \\
\hline $\begin{array}{l}\text { Cattle waste bonsumption per kWh } \\
\text { Biogas power plants }\end{array}$ & $\begin{array}{l}350 \text { MW considering 0.752 } \\
\text { m3 of biogas consumption } \\
\text { per kWh. }\end{array}$ & Mainly private sector \\
\hline
\end{tabular}

Table 1: Potentialities of renewable resources.

Other renewable energy sources include bio-fuels, gasohol, geothermal, river current, wave and tidal energy.

\section{Power sector}

Market overview: According to Bangladesh Power Development Board electricity demand in Bangladesh has been increasing by 200 MW per year since 1996. The total demand is projected to be more than 11497 MW by 2018 where contribution of public sector is 5933 MW, private sector is $5064 \mathrm{MW}$ and $500 \mathrm{MW}$ from import (Crossborder trading of $500 \mathrm{MW}$ power with India has began in October 2013). Possibilities of trading of hydropower from Nepal, Bhutan and Myanmar are being explored. Highest generation so far was $6675 \mathrm{MW}$ recorded on 12/07/2013 and it is increasing gradually.

Government has prepared the Power System Master Plan 2010 (PSMP 2010). The Bangladesh power sector master Plan indicates that to attain a 8\% GDP. According to the PSMP 2010 the estimated demand for power would be about 19,000 MW in 2021 and 34,000 MW in 2030 (ref: Power Division). It has been estimated that power outage in this country results a loss of annual industrial output of $\$ 1$ billion. Power is one of the prime reasons of slow GDP growth and the Government of Bangladesh (GOB) has recognized the power sector is 
a priority sector. GOB has decided to build more power projects through private sector and public private partnership [16-19].
Generation planning: Generation planning is given below.

\begin{tabular}{|l|l|l|l|l|l|l|l|}
\hline Fiscal year & $\mathbf{2 0 1 3}(\mathbf{M W})$ & $\mathbf{2 0 1 4}(\mathbf{M W})$ & $\mathbf{2 0 1 5}(\mathbf{M W})$ & $\mathbf{2 0 1 6}(\mathbf{M W})$ & $\mathbf{2 0 1 7}(\mathbf{M W})$ & $\mathbf{2 0 1 8}$ (MW) & Total (MW) \\
\hline Public & 763 & 889 & 1773 & 1285 & 450 & 1950 & 7110 \\
\hline Private & 50 & 1864 & 1087 & 1098 & 2166 & 0 & 6265 \\
\hline total & 813 & 2753 & 2860 & 2383 & 2616 & 1950 & 13375 \\
\hline
\end{tabular}

Table 2: Electricity capacity in private and public sector.

An assessment of achievements in power sector: Regardless of financial constraints and gas supply shortages, the government deliberates a strategy to overcome the crisis and at the same time meet the ever-increasing demand for power. It launched immediate, short, medium and long term programs to increase power supply through introduction of fuel mix (gas, coal, liquid fuel, nuclear energy and renewable), demand side management, energy efficiency and conservation. After assessing the latest demand, the government has revised its targets for increasing power generation. The year-wise details of the additional power generation programs, both in public and private, are listed below 57 plants with a capacity of about 4,432 MW have been commissioned, 33 plants with a capacity of 6,569 MW are under construction. 19 projects with a capacity of about 3,974 MW are under tendering process and 9 plants with capacity of 3,542 MW are at initial stages as shown in the Tables 2 and 3.

\begin{tabular}{|l|l|}
\hline Electricity Growth & 15\% FY-2014 (Av. 7\% since 1990) \\
\hline Derarted Capacity & $\begin{array}{l}\text { 9675MW (February, 2014, source: } \\
\text { BPDB) }\end{array}$ \\
\hline Generation Capacity & $\begin{array}{l}10241 \mathrm{MW} \text { (February, 2014, source: } \\
\text { BPDB) }\end{array}$ \\
\hline Maximum Generation & $6060.00 \mathrm{MW}$ ( 10th February 2014) \\
\hline Maximum Generation in History & $6675.00 \mathrm{MW}$ (12th July 2013) \\
\hline Peak demand & $9268 \mathrm{MW}(2014)$ \\
\hline Transmission Line & $9322 \mathrm{ckt} . \mathrm{km}$ \\
\hline Distribution line & $2,90,000 \mathrm{~km}$ \\
\hline Total Consumers & $14.2 \mathrm{Million}$ \\
\hline Newly connected people & 3.45 Million \\
\hline $\begin{array}{l}\text { Present generation Capacity by Public } \\
\text { sector }\end{array}$ & $58 \%$ \\
\hline $\begin{array}{l}\text { Present generation Capacity by Public } \\
\text { sector }\end{array}$ & $42 \%$ \\
\hline Reduction of System Loss(distribution) & $15.67 \%$ to 12.03\%. \\
\hline Per Capita Generation & $321 \mathrm{kWh}$ (incl. RE) \\
\hline Access to Electricity & $62 \%$ \\
\hline
\end{tabular}

Table 3: Bangladesh Power Sector at a Glance.

Demand supply situation (February 2014): Below variables are given
- Generation: 9675 MW (Capacity- 10241 MW).

- Highest so far: 6060 MW (February 2014).

- Gas shortage causes 600 - 800 MW less Power Generation.

- Peak Demand: 9268 MW.

- Load shedding situation is in zero level (demand 5599MW, 12th February 2014). But, load shedding up to $1000 \mathrm{MW}$ during hot summer days.

- Shortage and unreliable power supply has constrained economic growth.

Bangladesh has the fastest growing Solar Home System (SHS) in the world with over one million homes covered under the program being spear headed by IDCOL (a public infrastructure financing entity). Other projects include: $1 \mathrm{MW}$ solar hybrid system along with $5 \mathrm{MW}$ by diesel in Hatia island, 8 MW Solar PV plant in Kaptai, Solar Street lights in six City Corporation areas, replacement of diesel irrigation pump by Solar, $600 \mathrm{~kW}$ solar mini grid in a remote area Sullah, $11 \mathrm{KW}$ solar power to the CHT area, nearly $230 \mathrm{~W}$ solar power in Angorpota and Dahagram Chitmahal area. Solar PV with capacity of $21.2 \mathrm{KW}$ at the Bangladesh GOV has been installed as a demonstration project. Other line ministries have also undertaken projects on solar lighting. Bangladesh needs total US $\$ 22$ billion investments in the power sector to minimize this demand-supply gap. The revised private sector power generation policy of Bangladesh provides a number of incentives for the foreign investment in the power sector.

Prospective plan: The government of Bangladesh (GOB) has adopted Power System Master Plan (PSMP) 2010 as the basis for future projects to be undertaken in this sector. As per PSMP 2010, electricity generation would reach to $34,000 \mathrm{MW}$ by 2030 . With new generation addition, the total generation capacity would be about $16,500 \mathrm{MW}$ by FY 2018. By that time some power plants will be derated, contracts of some rental power plants will be over and the dependable capacity would be around 13,000 MW. Coal will be the dominating fuel in the future generation. Coal fire plants with capacity of $1320 \mathrm{MW}$ will be set up in Khulna. The Khulna plant will be set up in joint venture with BPDB of Bangladesh and NTPC of India. Besides, other coal fired plants will be set up in different locations of Khulna, Chittagong, Matarbari and Moheshkhali; 100-200 MW power will be generated from wind. Along with wind mapping, a flag ship wind power project with capacity of $15 \mathrm{MW}$ will be implemented within 2 years.

\section{Fisheries}

The country is crisscrossed with hundreds of rivers and it has established a credible record of sustained growth within a stable macro-economic framework where fisheries sector play an imperative 
and prospective involvement in agro-based pecuniary expansion, destitution easing, employment and delivering of animal protein and grossing the overseas exchange. Fish (including shrimp and prawn) is the second most valuable agricultural crop and its production contributes to the livelihoods and employment of millions. The key objectives of the sector are enhanced fisheries production; poverty alleviation through creating self-employment and improvement of socio-economic paradigm of the fishers; meet the demand for animal protein; achieve economic growth and earn foreign currency by exporting fish and fisheries products and maintain ecological balance; conserve biodiversity and improve public health. Bangladesh has achieved remarkable progress in the fisheries sector since its independence in 1971. Fisheries sector have been playing a very significant role and deserve potential for future development in the agrarian economy of Bangladesh. This sector contributes $4.39 \%$ to the national GDP and almost one fourth $(22.76 \%)$ to the agricultural GDP (Bangladesh Economic Review 2012). In recent years, this sector performs the highest GDP growth rate in comparison to other agricultural sectors (crop, livestock and forestry). The growth rate of this sector over the last 10 years is almost steady and encouraging, varying from 4.76 to $7.32 \%$ with an average 5.61 percent. Whereas last four years average growth rate of this sector is 6.22 percent. The country's export earnings from this sector are $2.46 \%$ in 2011-12. The sector's contribution to the national economy is much higher than its $4.39 \%$ share in GDP, as it provides about $60 \%$ of the animal protein intake and more than $11 \%$ of the total population of the country is directly or indirectly involved in this sector fortheir livelihoods. There are 4.024 [million] ha open water bodies in our country. Among them 0.85 million ha are rivers and estuaries, 0.18 miilion ha sundarbans, 0.11 million ha beel, 2.832 million ha floodplains and 0.69 million ha Kaptai. Beel is one of the best natural habitats for the indigenous fishes of different food habits of Bangladesh. Most of the aquatic species specially the fish and prawn enter in the inundated areas of the beel from the adjoining rivers and canals to feed and grow during the monsoon months. The 'beel' a Bengali term is used for large surface water body that accumulates surface runoff water through internal drainage channel. Bangladesh has thousands of beels, with the most common names being Chalan Beel, Gopalganj-Khulna Beel, Meda Beel, Aila Beel, Dekhar beel, Kuri Beel, Erali beel and Arial Beel. The average rate of production from beel is $714 \mathrm{~kg} / \mathrm{ha}$ which can be increased manifold.

Inland fisheries: The inland fishery resources of Bangladesh are considered to be unexcelled either in area or potential by any other inland fisheries of the world. Inland fisheries contribute nearly $90 \%$ to the total catch of fish in Bangladesh. Inland culture includes mainly pond/ditch, baor, shrimp/prawn farm, seasonal cultured water-body etc. covering an area of about 7.41 lakh ha and produces 17.26 lakh MT fish and shrimp in the 2011-12. Though the closed water area is only $15.55 \%$ of the total inland water-bodies, but $52.92 \%$ of the total yield comes from inland aquaculture. The inland water resources can be conveniently divided into the following categories:

- Open inland waters which include the rivers and their tributaries; 'baors', 'haors' and 'beels' connected at least occasionally with rivers and streams; and the estuaries. The main river system in Bangladesh includes the Padma, the Meghna, The Brahmaputra and the Karnaphuli and their tributaries. The baors comprise ox-bow lakes and other forms of defunct rivers. There are many large and small baors in Jessore district and several in the districts of Kushtia and Faridpur. Among the larger baors in Jessore, Baluhar Baor (272ha), Joydia Baor (207), Sasta Baor (187), Morjad Baor (292), Bergobindapur Boar (214) and Jhampa Baor (183) represent only a few. The haors, synonymously called beels, are natural depressions used partially as agricultural lands, and seasonally or perennially filled from adjacent rivers or monsoon waters. Most of the larger haors/beels are located in Sylhet, Mymensingh and Faridpur. Kakaluki Haor (36,437ha), Tangua Haor $(25,506)$ and Bardai Haor $(3,239)$ in Sylhet district, and Beel Meskha $(6,478)$ and Bengla Char Banda $(6,073)$ in Mymensingh are among the big freshwater and salt water. The estuarine region of Bangladesh is interspersed with numerous distributaries of rivers, inlets of the sea and defunct streams that are interconnected with numerous channels. The deltaic area in Bangladesh is an archipelago.

- Closed waters include ponds, dighis and tanks. For irrigation and other general purposes the feudal kings moharajas and land lords of the past had excavated tanks, dighis (larger tanks) and moats and thus set examples of their benevolent spirit for the good of their subjects. Simultaneously, well-to-do commoners also for their own requirements excavated quite a large number of tanks and dighis but of comparatively small size. As a result, water bodies of assorted shape and size are common almost everywhere in the country. In some places these ponds and dighis are widely scattered and, in some places in clusters or in groups. With political and social changes, the system of administration has also changed and the feudal system has since been abolished. All landed properties including the ponds owned by the Zamindars have been acquired by the Government. Due to continuous neglect most of these water bodies have turned into derelict waters. The number of such derelict ponds, dighis and canals are numerous.

Rivers and estuaries are major sources of fish fry which are collected and used for fish culture in closed and semi-enclosed waters. The major carps species e.g., Rui, Catla, Mrigal etc., occur throughout the larger river systems in Bangladesh where the sexually mature brood fish spawn during monsoon when rivers are in flood. Major spawning grounds of these valuable fish species include:

- Halda River - the lower reaches of the river from Sattaghat (near Gahira) to.

- Its confluence with the Karnaphuli River.

- Arial Khan River - the region near Madaripur.

- Garai River - near the general area of Kushtia.

- Ganges River - the area west of Rajshahi and estward in areas near Lalpur.

- Jamuna River - the regions adjacent to Sirajganj and near Fulchharighat.

- Old Brahmaputra River - the region north of Mymensingh.

Marine fisheries: In addition to the above inland waters, the Republic has an extensive shelf area of which 37000 sq. km (is no deeper that $50 \mathrm{~m}$. The entire shelf (down to $200 \mathrm{~m}$ ) covers an area of $67,000 \mathrm{~km}$. According to West, Bangladesh continental shelf covers an area of 27,000 mi (square miles) or $69,900 \mathrm{~km}$. Beyond this continental shelf is the deep sea. The segment of marine water extending from the coast line into the sea up to the limit of 12 miles $(19 \mathrm{~km})$ constitutes the territorial water of Bangladesh. The Republic reserves the exclusive right for exploitation of fisheries from this territorial water mass measuring approximately 1 million ha. The declared economic zone extends 200 miles $(320 \mathrm{~km})$ out to the sea from the coast line. There are many indications that the continental-shelf waters of Bangladesh are rich in fish, shellfish and other biological resources potential of the Bay of Bengal. 
Productions: The country has huge opportunities for the development of brackish water aquaculture boosting shrimp production and earning substantial amount of foreign currencies. Production of shrimp from culture and capture fisheries increased to a great extent in the beginning of 1980's. Since then, brackish water shrimp farming has been expanded to over 0.214 [million] ha of land by 2011 from 1.4 lakh ha in 1980. It is expected that with the introduction of improved scientific method of shrimp culture, the present production of shrimp will be increased substantially. The country has limited access to marine fisheries resources in the Bay of Bengal. Only demarsal fish and shrimp are being trapped from here. Other potential marine resources are yet to be exploited on commercial scale. Only $18 \%$ of total fish production comes from Marine capture fisheries and $82 \%$ from inland fisheries. The present democratic government has undertaken new policy for sustainable aquaculture production; provide need based aquaculture extension services, implements fish conservation activities which increase the national fisheries production as well as the growth rate in fisheries sector. Besides these, fisheries extension and conservation activities, AIGs and rehabilitation programs for poor fishers etc. were undertaken. Through the Execution of Fisheries Friendly Policy of the present government, total fish production has been increased from 2.7 million metric ton in 2008-09 to 30.62 lakh $\mathrm{mt}$ in $2010-11$ shown in the above Figure 1.

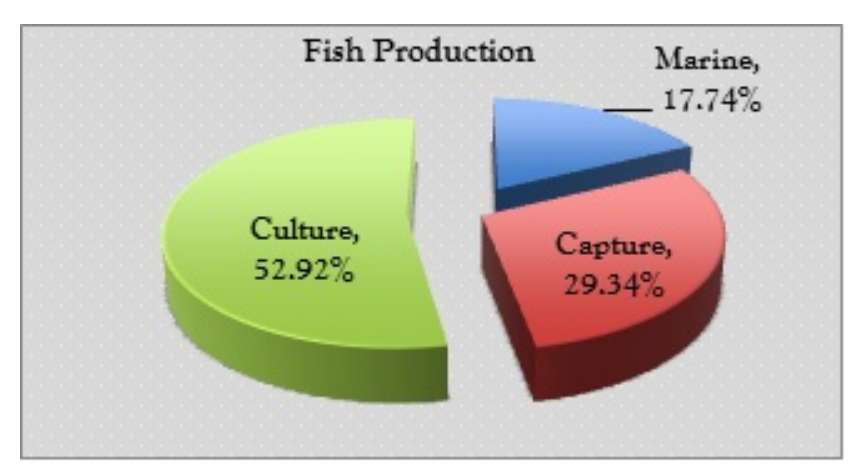

Figure 1: Fish production is sector wise.

\section{Fish and shrimp culture}

Fish Cultures: Pond aquaculture, Fish culture in paddy field, Fish culture in borrow-pit and khal, Fish culture in baor (Ox-bow lake), Cage culture, Pen culture, Integrated fish farming:

Pond aquaculture: Currently pond aquaculture has been practiced in a total area of about 3.5 lakh ha which is $7.4 \%$ of total inland water. Pond aquaculture is producing about $1199866 \mathrm{mt}$ fish which contributing $47.70 \%$ of total inland production in $2010-11$. The pond production involves composite culture produces an average $3430 \mathrm{~kg} / \mathrm{ha}$ whereas there are records of $63 \mathrm{mt} /$ ha production of pangas under intensive farming in Mymensingh region.

Fish culture in paddy field: Paddy fields and seasonal floodplains are promising and potential resources for aquaculture. It has been estimated that paddy fields cover an area of about 80 lakh ha of which 28.34 lakh ha floodplains which remain 4-5 months under water.

Fish culture in borrow-pit and khal: Different types of waterbodies improved under Integrated Fisheries and Livestock Development
Project in Flood Control, Drainage and Irrigation (FCDI) Project area and other waterbodies also included in the aquaculture systems.

Fish culture in baor (Ox-bow lake): A total of about 600 baors having an area of 5,488 ha are situated in the south west part of the country. Different development projects have been implementing to increase the fish production from baor. The total water area of baors have been developed and brought under improved aquaculture through fingerling stocking and management practices. Six baors of Jessore district were under disposal of DoF till Feb/2009 and now these baors are under disposal of Department of Fisheries according to the MoU signed between Ministry of Land and Ministry of Livestock and Fisheries for next 6 years. Besides this, 30 baors are managing by OLP-2 project of DoF with the financial support of IFAD. These baors covered area of 1137 ha and fish production has increased from $80 \mathrm{~kg}$ to $750 \mathrm{~kg} / \mathrm{ha}$ (DoF 2008). Local fisher communities are being involved in the baor management and improved their livelihood.

Cage culture: Cage aquaculture has been identified as a means of livelihoods for landless people. Northwest Fisheries Extension Project (NFEP) in Parbatipur, Dinajpur and Patuakhali Barguna Aquaculture Extension Project (PBAEP) demonstrated cage aquaculture as pilot basis. The production achieved through cage culture was encouraging and satisfactory but the activities were discontinued due to socioeconomic condition of the farmers and some constrains. Cage culture of monosex tilapia is being practiced in Chandpur, Laxmipur Faridpur, Barishal, Mymensingh, Dhaka, Munsigonj, Gopalganj and other regions of Bangladesh. In 2011, about 6750 metric ton fish produced from 6000 cages.

Pen culture: Pen culture is also one of the potential means of producing fish from vast water body or water channel. In recent years, pens are made with different materials like bamboo, net, iron-meshed, wooden pillar etc. The area of pen also varies in size from half to few ha. The fish species reared in the pen are carp, tilapia, pangas etc.

Integrated fish farming: The integration of aquaculture with duck and chicken production was begun experimentally at the BFRI, Mymensingh producing some promising results. The project demonstrated that 500 khaki Campbell ducks can be profitably raised on a 1 ha carp pond while also producing $4.5 \mathrm{t} / \mathrm{ha}$ of fish without any additional need for supplementary feed or fertiliser for the fish. The most promising integrated farming in Bangladesh however, is rice fish culture, Ameen reported on the technique from many parts of Bangladesh. Traditionally one or more sump pond(s) are constructed at the lowest corner of the paddy field where fish accumulate as the water level reduces, thus fish are harvested from the sump without any additional stocking or management practices being required.

Shrimp culture: The major shrimp producing districts are Bagerhat, Satkhira, Pirojpur, Khulan, Cox's Bazar and Chittagong, recently farmers especially in the Bagerhat and Pirojpur districts have begun shrimp farming in their paddy fields. Traditionally shrimp farming began by trapping tidal waters in nearby coastal enclosures known as 'gher' where no feed, fertilisers or other inputs were applied, with an increasing demand from both national and international markets farmers started to switch over into improved extensive and semiintensive systems. With the expansion of aquaculture, environmental degradation, biodiversity and the control of the outbreak of disease especially in the coastal farming operations have become the major issues. Shrimp post larvae (PL) collectors are estimated to destroy nearly 100 other species of flora and fauna while collecting post larvae of Penaeus monodon, moreover, the destruction of mangrove forest for 
coastal shrimp culture and the introduction of viral diseases in semiintensive farms has also become serious issues for concern. For inland aquaculture, habitat destruction, the use of insecticides and the introduction of diseases like epizootic ulcerative syndrome (EUS) have also become important issues. There are two types of culture:

- Shrimp (Bagda) Culture

- Shrimp (Golda) Culture

\section{Forest}

Bangladesh is an independent and sovereign state since December 1971. It has about 157.22052 million people (2014) that is $2.19 \%$ of worlds total and growing at about $2.1 \%$ per annum with about $80 \%$ of them living in rural areas in 59, 990 villages having average household size of 5.3 persons. The overall literacy rate is $32.4 \%$ but the literacy rate of women is about $50 \%$ of men. The population density is very high and it lays on the active delta of three major rivers viz Padma, Meghna and Jamuna and their numerous tributaries. The country covers an area of 1,47,570 sq. km and bounded by India from the west, north and most of east. Myanmar lies on the south eastern edge and Bay of Bengal on the south. Forest Resources are renewable resources which can provide timber, pulp, pole, fuel wood, food, medicine, and habitat for wildlife and primary base for biodiversity A small tract of higher land occurs in Sylhet, Mymensingh, Chittagong, Cox's Bazar and Chittagong Hill Tracts (CHT) regions. The south-western region consists of a large number of dead and cut-off rivers. The coastal part of Bangladesh includes the famous Sundarbans Mangrove Forest. A number of depressed basins are found in the district of greater Mymensingh and Sylhet which are inundated by fresh water during the monsoon that gradually dry out during the dry winter season. These depressed basins are known as 'Haor.' Climate of Bangladesh is subtropical and monsoon rainfall varies from $1200-3500 \mathrm{~mm}$. Rice is the major cereal crop while jute, sugarcane, and tea are the main cash crops. Other important crops are wheat, tobacco, pulses, vegetable and tree fruits. Garments, raw and manufactured jute goods tea, fish and hides and skins are the chief exports. Bangladesh is noted for its estuarine environment, yet less than $10 \%$ of its total water flow originates from its own catchments and rest comes from India, Nepal and Bhutan. Normally, $20 \%$ of the country gets flooded during the monsoon period.

Land and forest areas: Of the total area of Bangladesh, agricultural land makes up $65 \%$ of its geographic surface, forest lands account for almost $17 \%$, while urban areas are $8 \%$ of the area. Water and other land use account for the remaining $10 \%$. The total forestland includes classified and unclassified state lands and homestead forests and tea/ rubber gardens. In case of private forests, the data represent the treecovered areas.

Of the 2.52 million hectare Forest Land, Forest Department manages 1.52 million ha which includes Reserved, Protected and Acquired forest and Mangrove forest on the newly accreted land in estuaries of major rivers. The remaining 0.73 million ha of land designated as Unclassed State Forest (USF) are under the control of Ministry of Land. Village forests (homestead land) form the most productive tree resource base in the country and accounts for 0.27 million ha.

\section{Type of forests in Bangladesh}

Types of Forest: There are four types of forests, which have been managed, are as follows:
- Mangrove Forests

- Tropical evergreen and semi-evergreen forests

- Tropical moist deciduous Forests

- Village Forest

\section{Mangrove forest}

Natural mangrove forests: The largest single tract of natural mangrove forest is the Sundarban. It consists of a total of $6,01,700$ ha which is $4.07 \%$ of total land mass of the country and $40 \%$ of total forest land. Sundarban is a unique habitat for a number of wildlife. Among them some mammals are Bengal Tiger (Panthera tigris tigris), Gangetic Dolphin (Platanista gangetica), Monkey (Macaca mulatta), Indian Fishing cat (Felis viverrina), Indian Otter (Lutra perspicillata), Spotted Deer (Axis axis) etc. Reptiles like Estuarine Crocodile (Crocodylus porosus), Monitor Lizard (Varanus salvator), Rock Python (Python molurus) and Green Turtle (Chelonia mydas) etc. are found in the Sundarban.

Mangrove plantation: Mangrove afforestation along the entire southern coastal frontier is an innovation of foresters. During 1960-61, Government undertook afforestation programme along the shore land of coastal districts. This initiative got mementum from 1980-81 with the aid of development partners and afforestation programs are extended over foreshore islands, embankments and along the open coasts. Since 1965-66 up to 2012-2013, 1,96,000 ha of mangrove plantations have been raised under a number of coastal afforestation projects. The present net area of mangrove plantation is 132,000 ha after losing some area due to natural calamities.

\section{Tropical evergreen and semi-evergreen forests}

Tropical evergreen and semi evergreen forests are extended over Chittagong, Cox's Bazar, Chittagong Hill Tracts and Sylhet totaling an area of $6,70,000$ ha which is $4.54 \%$ of total landmass of the country and $44 \%$ of national forest land. Depending on topography, soil and climate these area are categorized as i) Tropical wet evergreen forests and ii) Tropical semi-evergreen forests.

\section{Tropical moist deciduous forests}

The Central and northern districts covering an area of 1,20,000 ha about $0.81 \%$ of total land mass of the country and $7.8 \%$ of the country's forest land are bestowed with Tropical Moist Deciduous Forests. This forest is intermingled with the neighbouring settlements and fragmented into smaller patches. Sal (Shorea robusta) is the main species there with other associates like Koroi (Albizzia procera), Azuli (Dillenia pentagyna), Sonalu (Cassia fistula), Bohera (Terminalia belerica), Haritaki (Terminalia chebula), Kanchan (Bauhinia acuminata), Jarul (Lagerstroemia speciosa), Jam (Syzygium spp) etc.

\section{Village forests}

Tree coverage in the village forests are 2,70,000 ha which acts as the source of a remarkable portion of national demand of forest produces. The latest inventory exhibits that a total of 54.7 million cubic meter [cum] forest products are available in this village forests.

\section{Forest products}

NWFP (Non Wood Forest Products): Some of the important nonwood forest products are listed below: 
Page 8 of 13

Bamboo (Melocanna baccifera, Bambusa tulda etc, Sungrass (Imperata spp.), Cane (Calamus, viminalis,Calamus guruba):., Pati Pata / Murta (Clinogynae dichotoma, Gol-Pata (Nypa fruticans): Leaves, Bark and Fruits"Kurus pata", Honey,Shells, Conch-Shells, oysters etc.

\section{Revenue earnings from the forest sector}

We observed an upward trend of revenue earning excluding 2013-14 fiscal year as it was partially calculated (till august 2013) as shown in the Figure 2.

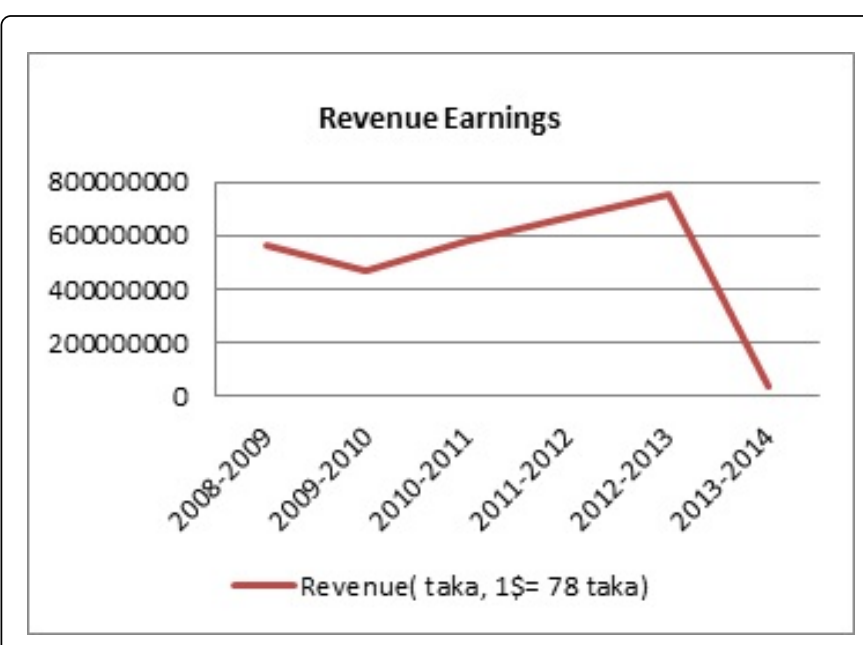

Figure 2: Revenue earnings from Forest sector.

\section{Water resources}

The country is bounded by India on the west, the north and the northeast; Myanmar on the southeast and the Bay of Bengal on the south. The area of the country is 147,570 sq.km. The country is the lowest riparian of the Ganges basin, the Brahmaputra basin and the Meghna basin. Most of its area is low lying floodplain formed by the alluvial soil deposited by three great rivers, namely the Brahmaputra/ Jamuna, the Ganges and the Meghna. These rivers drain a catchment area of about 1.72 million $\mathrm{km} 2$ in India, Nepal, China, Bhutan and Bangladesh; only 8 percent of the catchment area lies within Bangladesh. These major rivers and their tributaries have their headwaters outside Bangladesh with about $90 \%$ of their annual flow originating outside the country. This flow has a huge annual variation, with the combined flow of the Ganges and the Brahmaputra typically increasing from less than 10,000 cubic meter per second [cumec] early in the year to a peak of 80,000 to 140,000 cumec by late August to early September. Shortage of water in the dry season in Bangladesh is exacerbated by the diversion of water at the Farakka Barrage, just upstream of where the Ganges enters Bangladesh. The country contains about $22155 \mathrm{~km}$ of river length for about 700 rivers. The Rivers and water bodies occupy about $5 \%$ of the land surface. The land topography is almost flat with little hilly areas in the southeastern part.

The country enjoys tropical monsoon climate with two prominent seasons; dry season (November-May) and wet season (June-October). Bangladesh is predominantly an agricultural country; about $54 \%$ of the lands are used for crop production. Up to $85 \%$ of the annual rainfall occurs between June and September. Mean annual rainfall ranges from about $1200 \mathrm{~mm}$ in the west to almost $6000 \mathrm{~mm}$ in the northeast. The average annual rainfall in the Himalayas and in the Meghalaya hills to the north of Bangladesh reaches about $10,000 \mathrm{~mm}$. About $25 \%$ of the country is flooded to varying degrees each year during May through September when over $60 \%$ of the cereals is produced. Recurrent flooding severely restricts the farmers' choice of cropping to traditional low yielding broadcast variety of rice that can thrive in deep water and, in fact, the coverage is dominated by it. The real production potential is not harnessed due to flood depth. On the other hand, scarcity of irrigation water during March-April limits the cultivation of High Yielding Variety rice that accounts for about $36 \%$ of total rice production.

\section{Sources of water in Bangladesh}

The sources of water in Bangladesh are surface water, groundwater and rainwater. The Ganges-Brahmaputra-Meghna river system discharges huge amount of surface water through Bangladesh, a part enters into ground to form groundwater. About $93 \%$ of the stream flow passing through the country originates from outside the Bangladesh. Rainfall within country contributes to the total water available in Bangladesh, a part of which infiltrates into ground to recharge existing groundwater and the remaining rainwater flows as surface run-off. These sources of water available for the development of water supplies have their relative advantages and disadvantages in Bangladesh context. The availability of water in terms of quantity and quality, present situation and problems associated with the sources have been discussed in the following sub-sections.

\section{Surface water}

Surface water is abundant in the wet season in Bangladesh. An estimated 795,000 million cubic meter (Mm3) of surface water is discharged through the Ganges-Brahmaputra system, in the downstream of the confluence of the Ganges and the Brahmaputra. This is equivalent to $5.52 \mathrm{~m}$ deep water over a land area of 147,570 sq.km. There are other rivers discharging surface water into the Bay of Bengal. An average annual rainfall of $2.40 \mathrm{~m}$ within the country partly replenishes surface water sources. Each year about one-third of Bangladesh is submerged in a normal flood, and the area submerged may increase to about two-thirds during severe floods. In the dry season water scarcity persists in many areas. In this period surface water is only available in part of the $22,155 \mathrm{~km}$ of major rivers, 1,922 $\mathrm{km}^{2}$ major standing water bodies and about $1,475 \mathrm{~km}^{2}$ of ponds in the country. Surface water irrigation systems in the country compete for this available water in the dry season. The perennial water bodies are decreasing with the use of more and more surface water.

\section{Ground water}

The main source of ground water is the recharge from surface water. Most of the areas of Bangladesh have been formed from the sedimentary alluvial and deltaic deposits of three major rivers. These alluvial deposits have formed mainly an unconfined aquifer for most of the area of the country. Groundwater was supposed to be one of the major natural resources of the country except the safe drinking water supplies. But the presence of Arsenic in shallow aquifer has completely changed the situation. It is estimated that about $16 \%$ of present population of 123.15 million is exposed to arsenic contamination exceeding Bangladesh standard $(0.05 \mathrm{mg} / \mathrm{l})$. About $74452 \mathrm{sq} . \mathrm{km}$. of groundwater use area (about $50 \%$ of the country) is unsuitable for use by hand tubewells (as a source of drinking water according to WHO standard) due to arsenic. 
Page 9 of 13

\section{Water demand and supply}

Demands arise from several factors such as, natural (evapotranspiration), water supply, irrigation, fisheries and livestock, industrial, navigation and the environment (demands for salinity control). Proportion of total water demands, as projected for 2025, is estimated to be: instream-56\%, agriculture-32\%, environment- $9 \%$ and water supply-3\%. So, consumptive use comes to be $44 \%$. Environmental flow requirements according to IUCN as stated by Saleh should at least be $30 \%$ of the world's river flows so as to maintain a fair condition of freshwater ecosystems.

\section{Land resources}

Total Geographical area of Bangladesh is about 56,000 square miles (143,998 square kilometer). Out of which about 9 million hectares are cultivable land. A government survey finds that total cropped land is nearly 14.1 million ha including single, double and triple cropping land. It is estimated that the growing population pressure will use up 50 per cent of the country's cultivable land by $2025^{1}$.

Every person working in the agriculture sector now owns only an average of 0.12 ha of cropland. According to the classification of land, out of the total area, 63 per cent are being used for cultivation while 4.38 per cent for rural and urban housing and the rest includes forest and cultivable waste land ${ }^{2}$.There are two types of land in Bangladesh

- Khas land.

- Adivasi land.

\section{Landlord and land mafias}

More or less all state owned lands including 3.3 million acres of khas lands and new lands surfaced from the rivers and sea are occupied by the land grabbers, land mafias and terrorists under the patronage of former governments in power living in both rural and urban areas of Bangladesh.

\section{Poor people's access}

According to government report ${ }^{3} 57 \%$ people of Bangladesh are landless poor and they live below poverty level. But Non-Government sources say that the number of landless people in Bangladesh is more than 68\%. They live in perpetual poverty, hunger, disease and deprivation. According to Dr. Mahboob Hossain and Prof. Abdul Byes, $45 \%$ of the landless and poor marginalized peasants in the rural areas own only $5 \%$ of the total cultivable land of Bangladesh and receives $10 \%$ needed credit from institutional sources.

\section{Land occupy by the rich}

$22 \%$ of the rich and middle farmers of rural areas of Bangladesh own $71 \%$ of the total land and receive $31 \%$ institutional credit.

\section{An Overview of Non-Renewable (Natural Gas, Coal, Oil, White Clay, Sand, Rock, Gold) Resources of Bangladesh}

Geographically, Bangladesh occupies a bigger part of the Bengal basin and the country is roofed by Tertiary folded sedimentary rocks (12\%) in the north, north eastern and eastern parts; uplifted Pleistocene residuum (8\%) in the north western, mid northern and eastern parts; and Holocene deposits (80\%) consisting of unconsolidated sand, silt and clay. The oldest exposed rock is the Tura Sandstone of Palaeocene age but older rocks like Mesozoic, Palaeozoic amid Precambrian basement have been encountered in the drill holes in the north western part of the country. The imperative mineral deposits of Bangladesh are natural gas, coal, limestone, hard rock, gravel, boulder, glass sand, construction sand, white clay, brick clay, peat, and beach sand heavy minerals because of its different biological environment. Tertiary Barailshales stirring within the oil and gas windows have generated natural gas and oil found in Bangladesh. Sustainable mineral resources are still playing a vital role in shaping the modern civilized industrial world. Modern urbanization, industrialization, transportation and communication systems are the achievements of worldwide sustainable mineral resource development and their proper utilization in various sectors. Richness in natural resource is the key indicator of socio-economic infrastructure for any country all over the world. Strong technological know how its ability to explore and exploit mineral resources, and its wisdom in utilizing those resources properly in the development activities of the nation.

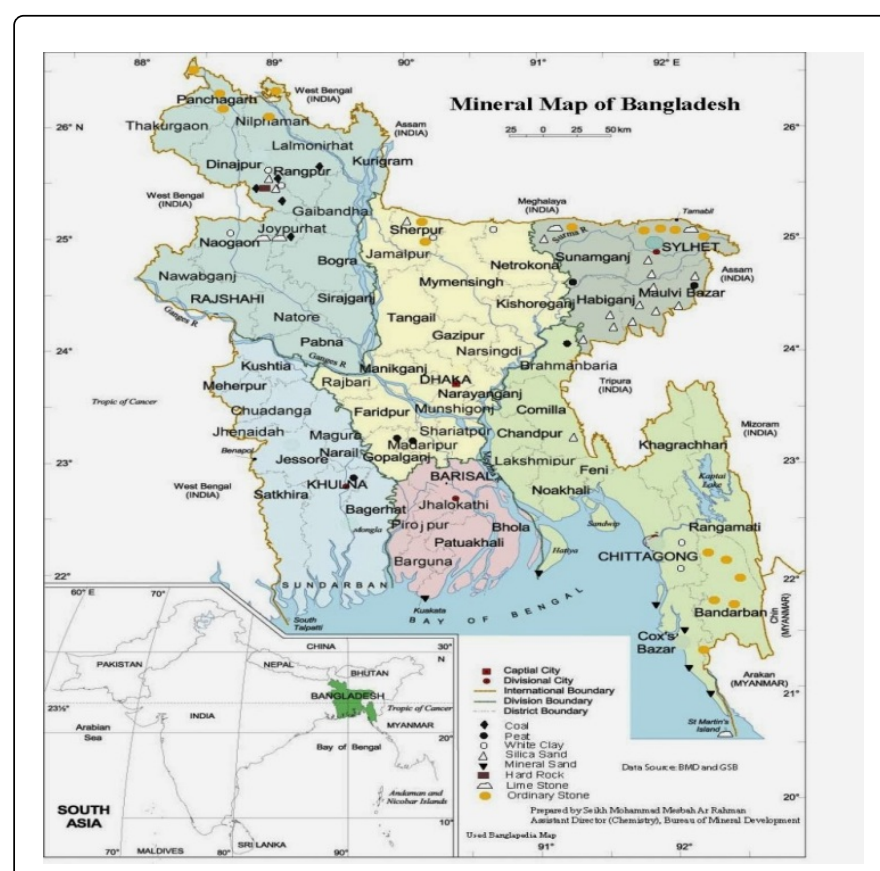

Figure 3: Mineral Map of Bangladesh.

Developing world is generally far behind compared with developed world in the sense of development activities. At present, natural gas is the only mineral commodity significantly contributing to the national

For detail see the report, "Needs for land and agrarian reform", prepared by ARBAN

ibid.

ARBAN 
Page 10 of 13

economy. Majority of the country's energy needs are met by gas that is about $90 \%$. Energy is the key ingredient for socio-economic development of a country and economic development depends on the adequate energy supply that leads a country self reliant. Ministry of Power, Energy and Mineral Resources divided into two departments namely Energy and Mineral Resources Department and Power Department. Energy and Mineral Resources Department that entrusted to make all policies connected to natural gas, liquid petroleum and mineral resources. EMRD is responsible to create policies and administrative control over Geological Survey of Bangladesh, Petrobangla, Bureau of Mineral Development and Department of Explosives. Hydrocarbon Unit and Bangladesh petroleum Institute is controlled and watches over by EMRD as shown in the Figure 3.

\section{Natural gas}

Natural gas has a vital role to play in our socioeconomic development as a rudimentary source of energy. Its widespread use in power, fertilizer, industry and household has made it the energy of choice in Bangladesh that accounts for about $73 \%$ commercial energy of the country. It is pretty cheaper than other conventional sources of energy that we import from abroad. The use of indigenous natural gas has, indeed, helped to accelerate the pace of economic development and improve the quality of our life in the country. So far in Bangladesh 25 gas fields have been discovered with the rate of success ratio is 3.1:1 of which two of the gas fields are located in offshore area. Gas is produced from 20 gas fields ( 79 gas wells), 15 are state-owned and the remaining operated by international oil companies. Currently, Chevron contributes more than half of Bangladesh's total gas production. Bangladesh gas sector started its journey in early 60 s, but its rapid expansion and integration stared to accelerate in 70 s spurred by the raising oil price. Total recoverable proven and probable gas reserve from discovered 25 gas fields has been estimated as 27.04 trillion cubic feet [TCF] out of which estimated proven recoverable reserve (P1) is 20.70 TCF and recoverable probable reserve is 6.39 TCF. Up to December 2013 as much as 11.92 TCF gas has been produced leaving only 15.12 TCF recoverable gas. Currently 19 gas fields are in production and out of 104 wells located in 19 gas fields, 84 are in stream. A total of 600.86 billion cubic gas (BCF) was produced in FY 2007-2008, 653.57 BCF in 2008-2009, 703 BCF in 2009-2010, 708.92 BCF in 2010-11, 743.57 BCF in 2011-2012 and 805.67 BCF in 2012-13. The demand for gas has already surpassed 2700 million cubic feet [MMCF] per day whereas the peak supply of gas is nearly $2287 \mathrm{MMCF}$ leaving shortfall of 413 MMCF per day. Against this backdrop, Petrobangla has drown time bound program to boost up gas production in the coming days, and with this end of view, short term, mid-term and long term (up to 2015) have been taken up for enhancing gas production to and additional amount of $1560 \mathrm{mmcfd}$ with in the year 2015 as envisaged in the road map. Meanwhile, a volume of about $593 \mathrm{mmcfd}$ of gas added to the natural grid.

Average daily gas production capacity is about $2000 \mathrm{mmcfd}$ of which International Oil Companies (IOC) produce $1040 \mathrm{mmcfd}$ and State Owned Companies (SOC) produce $960 \mathrm{mmcfd}$. The gas production recorded on 24 February, 2010 was 1996.7 mmcfd. At present the daily approximate projected gas demand throughout the country is $2500 \mathrm{mmcfd}$. The demand is increasing day by day. Energy and Mineral Resources Division (EMRD) has already undertaken an array of short, medium, fast track and long term plans to increase gas production to overcome prevailing gas shortage. According to this plan 188 mmcfd, 290 mmcfd, 995 mmcfd (including 500 mmcfd LNG), 500 mmcfd and 380 mmcfd gas will be added to the national gas grid by the year 2010, 2011, 2012, 2013 and 2015 respectively. After completion of these plans production capacity is expected to increase to about $2353 \mathrm{mmcfd}$ gas by December 2015. To increase the gas production more programs will be taken in near future. Bangladesh's natural gas output increased only by 110 million cubic feet per day to 2.26 billion cubic feet per day until June 2013 from 2.15 BCF per day in June 2012, Petrobangla data indicated. Amid annual estimated demand growth of 10 percent, the country's entire recoverable gas reserves of 16.36 trillion cubic feet are expected to continue to 2025 and beyond, although in short supply. In a forecast of gas supply scene from the existing gas fields, production is expected to increase and reach its peak in 2016. As the demand for gas continues to grow, the gap between demand and supply will continue to widen as the production begins to decline after 2016. But if the natural gas consumption rate should exceed that 10 percent growth estimate, Bangladesh's reserves won't last more than a decade. The government's decision for over production raises questions, since it came without measuring the capability for over production of a gas field. In 2009, when the Awami League came to power, the country's gas supplies hovered around 1850-1900 mmcfd, a few hundred mmcfd short of the demand. Over the next five years, the supplies increased up to 2,250 mmcfd due to increased production by the national gas companies. Chevron alone provided $250 \mathrm{mmcfd}$. And now it is investing half a billion dollars to increase Bibiyana Gas Field's production by 300 mmcfd by early next year to address the country's gas crisis. Experts believe that this might cause Bibiyana to collapse just as Sangu did in the past. Besides over production, the lack of proper management and surveillance also poses some problem as shown in the Figure 4.

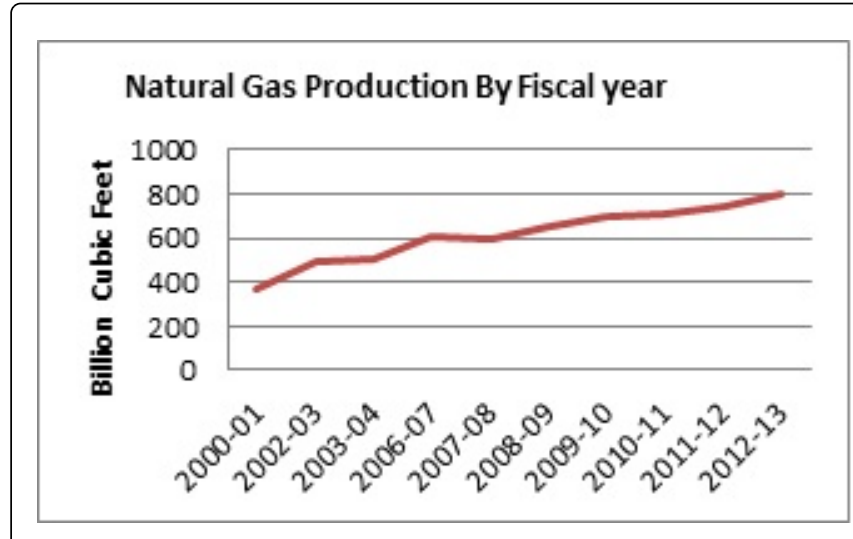

Figure 4: Natural gas production by fiscal year.

\section{Petroleum product}

Bangladesh imports annually about 1.3 million metric tons of crude oil. Besides these, another 2.7 million metric Tons (approx) of refined petroleum products per annum is imported. Condensate is mixed with crude oil. Major consumer of liquid fuel is transport sector followed by agriculture, industry and commercial sector which is mostly met by imported liquid fuel. Eastern Refinery Limited (ERL), a subsidiary company of Bangladesh Petroleum Corporation (BPC), is capable of processing 1.3 million metric Tons of crude oil per year. 


\section{Oil}

The only oilfield of the country has been discovered at Haripur in 1986 that is located in near Haripur in the eastern hilly district of Sylhet, but these have yet to be developed. The Haripur reserves are estimated at 40 million barrel [mbbl], with a recoverable reserve of about 6 million barrels and the total resource is likely to be much higher. For meeting the total requirement of commercial energy, Bangladesh imports yearly about 1.3 million metric Tons of crude oil. in 1959 was at great depth. Geological survey of Bangladesh (GSB) continued its efforts for exploration that resulted in the discovery of 4 coalfields. BHP Minerals, a US-Australian company, discovered a field in 1997 totalling 5 coalfields. Coal reserves of about 3.3 billion tons comprising 5 deposits at depths of 118-1158 meters have been discovered so far in the north-western part of Bangladesh. The name of these deposits are-Barapukuria, Phulbari and Dighipara coal field in Dinajpur district, Khalashpir in Rangpur district and Jamalganj in Joypurhat district as shown in the Table 4.

\section{Coal}

As well natural gas, Bangladesh has significant coal reserve. Coal first discovered in the country by Geological Survey of Pakistan (GSP)

\begin{tabular}{|l|l|l|l|l|l|l|l|l|}
\hline Coal Field & Depth $(\mathbf{m})$ & Thickness $(\mathbf{m})$ & $\begin{array}{l}\text { Area } \\
\text { (Squ km) }\end{array}$ & $\begin{array}{l}\text { Reserve (m } \\
\text { ton) }\end{array}$ & $\begin{array}{l}\text { Fixed } \\
\text { carbon (\%) }\end{array}$ & $\begin{array}{l}\text { Volatile } \\
\text { matter (\%) }\end{array}$ & $\begin{array}{l}\text { Ash content } \\
(\%)\end{array}$ \\
\hline Jamalgunj & 640.1158 & 64 & 11.06 & 1053 & $47(\mathrm{av})$ & $38(\mathrm{av})$ & $22(\mathrm{av})$ \\
\hline content (\%) & $\begin{array}{l}\text { Calorific value } \\
\text { BTU/lb }\end{array}$ & $0.62(\mathrm{av})$ \\
\hline Barapukuria & 129.506 & 51 & 5.25 & 300 & $45.5-54.7$ & $2.28-3.60$ & $11.79-23.71$ & $0.43-1.33$ \\
\hline Khalapir & 257.483 & 50 & 12.56 & 143 & $32.0-80.8$ & $2.93-30.47$ & $7.6-50.51$ & $0.34-2.15$ \\
\hline Dighipara & $328-407$ & 61 & N.D & N.D & $51.3-65.6$ & $25.29-38.23$ & $2.64-20.05$ & $0.51-1.02$ \\
\hline Phulbari & 152 & NA & NA & 386 & NA & NA & NA \\
\hline
\end{tabular}

Table 4: Coalfields and coal quality. Source: Asian Mining Year Book (Seventh Edition), 2001: ND: Not determined.

\section{White clay}

White Clay occurs in Sherpur, Netrokona, Dinajpur and Chittagong district etc. and it is used to make crockery's, sanitary materials, insulator and tiles. In addition, it is also used in Paper, cement and sugar industries. There are surface to near surface deposits of white clay in Bijoypur and Gopalpur area of Netrokona district, Nalitabari of Sherpur district, Haidgaon of Chittagong district and BaitulIzzat of Satkaniaupazila, Chittagong district. Besides, there are subsurface deposits of white clay in Maddhyapara, Barapukuria, Dighipara of Dinajpur district and Patnitala of Naogaon district. The showing white clay is not good in quality that is used in the ceramic factories of Bangladesh after mixing with high quality imported clay.

\section{Glass sand}

Important deposits of glass sand of the country are at Balijuri (0.64 million $\mathrm{t}$ ), Shahjibazar (1.41 million $\mathrm{t}$ ) and Chauddagram (0.285 million $\mathrm{t}$ ) at or near the surface, Maddhyapara (17.25 million $\mathrm{t}$ ) and Barapukuria ( 90.0 million $t$ ) below the surface. Glass sands consist of fine to medium, yellow to grey quartz. Total deposit is about 109.58 million t. Glass sand is used to make crockery's, lenses, glass sheet of windows and doors. It is further used to make quartz clock, frame of boat and aeroplane, foam glass and in various electronic equipments etc. Silicon chips are also made from silica, which is a main ingredient of glass.

There are two types of glass sand according to geological status.

- Recent piedmont alluvium in the eastern zone.

- Underground glass sand in the northern zone.

\section{Limestone}

It occurs in Sunamgonj, Takergat, Jahanpur, Paranagor, Joypurhat and St. Martin's Islands. Limestone is a very important mineral resource for Bangladesh. It is primarily used in cement industry. Limestone is used to make lime and cement and in paper, Ispat, sugar, glass industry. It is also used to decorate the building In Bangladesh limestone is found in Taker Ghat, Lalghat and Bangli Bazar of sylhet area, Jaypurhat and Saint-mertine of Cox's Bazar district. The lime stone of Takerghat limestone mining project is supplied to Chattak Cement Factory.

\section{Ilmenite, Garnet, Zircon, Kyanite, Magnetite, Rutile, Leucoxine, Monazite}

All these are found in Cox's Bazar and Teknaf Beach, Kuakata Beach, Moheshkhali, Nijhum dwip, Kutubdia and Monpura Island. Ilmenite, Rutile and Leucoxine are used to make slag and in welding and in melting of metal. They are used as a dyeing subject and Refractory Brick. Ilmenite is used to make sand blasting and heavy mud as an alternative to Barite in drilling activities. Titanium metal, which is derived from this mineral, is used to make frame of aeroplane, missile, and in chemical reaction and salt removal process. Zircon is used to make foundry sand, Refractory brick and as a dyeing substance. Zirconium is used as a radioactive substance. Monazite is used to make catalyst, television tube, refractory substance, thermal insulator substance and in computer disk and line printer.

\section{Peat}

Deposits of peat occur at shallow depths in different low-lying areas of Bangladesh like Gopalganj, Madaripur, Khulna, Sylhet and Sunamganj district etc. the reserve of dry peat is about 170 million $t$. In 1953, a large scale of peat was discovered at Baghia-Chanda Bil in 
Page 12 of 13

Faridpur and at Kola Monja in Khulna. The major deposits are in greater in the districts of Faridpur (150 million $\mathrm{t}$ ), Khulna (8 million $\mathrm{t}$ ). Peat requires drying before making briquettes for use as fuel. It is used as an alternative fuel to household, in brick and lime industries and in thermal power plant, and it requires drying before making briquettes for use as fuel. Petrobangla implemented a pilot project for extraction of peat and making briquettes but the result were discouraging and not economically feasible at current stage.

\section{Hard rock}

It occurs at Maddyapara in Dinajpur district and has been discovered by GSB (Geological Survey of Bangladesh) at depth 132-160 m below the surface. The Rock Quality Designation (RQD) of fresh rock varies from $60 \%$ to $100 \%$. The Maddhayapara project is extended over a wide range of area, from Baborgonj and Mithapukur of Rangpur district to Fulbari and Parbatipur of Dinajpur district and its capacity to recover 1.65 million t hardrock every year. It is used in construction such as road, highway, and railway track, regulator dam, river training, and river bank erosion. It is also used as construction material and as mosaic stone.

\section{Gravel deposit}

Deposits of gravel are found along the piedmont area of Himalyas in the northern boundary of Bangladesh. It occurs in Lalmonirhat, Panchagar, Sylhet district, Greater Chittagong and Chittagong Hill Tracts. These river borne gravels come from the upstream during the rainy season. It is used to construct buildings, road, railway, bridge and in river training and flood control. A total reserve of gravel is about 10 million cubic meters.

\section{Metallic minerals}

GSB has carried out investigation for mineral deposits and succeeded in locating a few potential zones. Relatively high content of metallic minerals like chalcopyrite, bornite, chalcocite, covelline, galena, sphaleriteetc have been found in the core samples from the north-western region of the country.

\section{Construction sand}

It is very much available in the river beds throughout the country. Sand consists mostly of quartz of medium to large grains. It is extensively used as construction materials for buildings, bridge, roads all over the country as shown in the Table 5.

\begin{tabular}{|c|c|c|c|c|}
\hline $\begin{array}{l}\text { Name of } \\
\text { the Mineral }\end{array}$ & Place & $\begin{array}{l}\text { Estimated } \\
\text { Reserve } \\
\text { (Probable) } \\
\text { (million ton) }\end{array}$ & District & Remarks \\
\hline \multirow{4}{*}{ Coal } & \#Jamalganj & 1053 & Joypurhat & \multirow{4}{*}{$\begin{array}{l}\text { \#Development } \\
\text { of Barapukuria } \\
\text { Coal field is } \\
\text { going } \\
\text { Discovered in } \\
\text { July/, 1995. }\end{array}$} \\
\hline & \#Barapukuria & $300^{*}$ & Dinajpur & \\
\hline & \#Khalashpir & 143 & Rangpur & \\
\hline & Dighipara & 150 & Dinajpur & \\
\hline \multirow{3}{*}{ Peat } & Baggie Chanda & 150 & Gopalganj & \multirow{3}{*}{$\begin{array}{l}\text { Instead of fuel } \\
\text { wood may be } \\
\text { used as fuel. }\end{array}$} \\
\hline & Kolamouza & 8 & Khulna & \\
\hline & Chatalbil & 6.21 & Sunamganj & \\
\hline
\end{tabular}

\begin{tabular}{|c|c|c|c|c|}
\hline & $\begin{array}{l}\text { Paula, } \\
\text { Sunamganj }\end{array}$ & 3.5 & & \\
\hline & Moulavibazar & 3 & & \\
\hline \multirow{5}{*}{ Limestone } & Jaypurhat & 100 & Jaypurhat & \multirow{5}{*}{$\begin{array}{l}\# 612371 \mathrm{t} \text { of } \\
\text { limestone from } \\
\text { Takerghat have } \\
\text { been exploited } \\
\text { During 1972-93 }\end{array}$} \\
\hline & Bagalibazar & 17 & Sunamganj & \\
\hline & \#Takerghat & 12.9 & Sunamganj & \\
\hline & Lalghat & 12.9 & Sunamganj & \\
\hline & Naogaon & -- & Naogaon & \\
\hline \multirow{5}{*}{ White clay } & Barapukuria & 25 & Dinajpur & \multirow{5}{*}{$\begin{array}{l}\text { \#109541 } \mathrm{t} \text { of } \\
\text { whit clay from } \\
\text { Bijoypur have } \\
\text { Been exploited } \\
\text { during 1972-93 }\end{array}$} \\
\hline & \#Bijoypur & 25 & Netrakona & \\
\hline & Maddyapara & ** & Dinajpur & \\
\hline & Dighipara & ** & Dinajpur & \\
\hline & Patnitala & & Naogaon & \\
\hline \multirow{8}{*}{ Glass sand } & Barapukuria & 90 & Dinajpur & \multirow{8}{*}{$\begin{array}{l}\# 94773 \mathrm{t} \text { of } \\
\text { glass sand have } \\
\text { been exploited } \\
\text { during 1975-93. }\end{array}$} \\
\hline & Maddyapara & 17.25 & Dinajpur & \\
\hline & Bhatera & 8 & Moulvibazar & \\
\hline & Shahajibzar & 0.3 & Habiganj & \\
\hline & and Bahubal & 0.17 & Comilla & \\
\hline & \#Chaddagram & ** & Sherpur & \\
\hline & Baljiuri & & Dinajpur & \\
\hline & Dighipara & & & \\
\hline Hard rock & Maddyapara & $\begin{array}{l}115 \\
\text { (Exploited) }\end{array}$ & Dinajpur & $\begin{array}{l}\text { Mine } \\
\text { development } \\
\text { activities } \\
\text { going on. }\end{array}$ \\
\hline \multirow{4}{*}{$\begin{array}{l}\text { Gravel } \\
\text { deposit }\end{array}$} & Bholaganj & 4 & Sunamgaj & \multirow{4}{*}{$\begin{array}{l}\text { Gravel deposits } \\
\text { are being } \\
\text { exploited from } \\
\text { different places } \\
\text { of the country. }\end{array}$} \\
\hline & Tetulia & 2.5 & Pachagarh & \\
\hline & Patgram & 2.5 & Lalmonirhat & \\
\hline & $\begin{array}{l}\text { Chittagong Hill } \\
\text { Tract }\end{array}$ & 1 & Chittagong & \\
\hline $\begin{array}{l}\text { Mineral } \\
\text { sand }\end{array}$ & $\begin{array}{l}\text { Sea beach of } \\
\text { Cox's Bazar, } \\
\text { Moheshkali, } \\
\text { Kutubdia and } \\
\text { Kuakatha. }\end{array}$ & & & \\
\hline
\end{tabular}

Table 5: Estimated reserve of Mineral resources. ${ }^{*}$ Reserves are in million tones except that of gravel that is in million cubic metre. ${ }^{\star *}$ Reserves have not yet been estimated.

\section{Beach sand}

This may be potential source in the future. Deposits of beach sand have been identified in the coastal belt, and in the coastal island in Bangladesh. Deposits of beach sand have been identified in the coastal belt and in the coastal islands of Bangladesh. Different heavy minerals and their reserves (in ton) are: Zircon $(158,117)$, Rutile $(70,274)$, 
Ilmenite (1,025,558), Leucoxene (96,709), Kyanite $(90,745)$, Garnet $(222,761)$, Magnetite $(80,599)$ and Monazite $(17,352)$. An Australian company has applied for the permission to carry out the feasibility study for exploitation.

\section{Brick clay}

In Bangladesh the mineralogical, chemical and engineering properties of Pleistocene and Holocene brick clays of Dhaka, Narayanganj and Narsingdi districts are well documented. The bulk chemistry and engineering properties of the Holocene and Pleistocene samples have been found satisfactory for manufacturing good quality bricks. These are being exploited and widely used in the country.

\section{Black gold}

Black gold is a very valuable mineral resource. Among it, the main are zircon, monazite, riotile etc. It is discovered in Cox's Bazar.

\section{Concluding Remarks and Recommendation}

The summary of this paper exhibits that there is a considerable opportunity of Bangladesh to boost the economic growth through renewable and non-renewable resource. With the help of these resources Bangladesh can generate electricity and can meet the required demand in the future. Therefore, the Government and the Private sector should work hand to hand to emphasize more renewable energy sources to produce electricity to solve our power crisis problem. Renewable energy sources discussed above can help Bangladesh to produce more power in order to reduce Load-shedding problem. Time has come to look forward and work with these renewable energy fields to produce electricity rather than depending wholly on conventional method. In addition, we observed that Bangladesh has a huge amount of natural Gas and other mineral resources. Proper and corruption free management can be able to solve the problem of energy crisis. I am trying to show that solar power is the emerging sector of Bangladesh that meets the majority portion of the energy and power demand in Bangladesh. Besides these forests, fishery, land, water and other nonrenewable resources are abundant in Bangladesh. These nonrenewable resources can help to boost the GDP growth in Bangladesh if government of Bangladesh comes forward to take healthy steps to reduce the corruption from natural resources sector from the country. Bangladesh, a country with a very low per capita GDP, is suffering from mounted pressure of huge population and ever-increasing budget deficits. Effective management of natural resources can help to reduce this problem and save the country from budget deficit. Conservation of forest is needed to stop the deforestation and enhance the environmental quality. Government has to produce strong laws and order and reformulate the existing laws for forest conservation. Different environment programs have to be undertaken to plant ecofriendly tress forestation. The rural and marginal poor should guarantee access to water bodies such as beel, haors, and baors. Right to safe drinking water has to be ensured for the citizens. I discussed previously, rain water is abundant in Bangladesh and proper utilization of rain water could be developed to stop overwhelming demand on ground water. Government should take necessary steps with regard to National Fisheries Policy importance of conserving fish breeding grounds and habitats, especially in relation to water management infrastructure such as flood control, irrigation and drainage projects. Finally, government has to introduce advanced technology to extract mineral resources and appropriate laws should be enacted to get the best outcome from natural resources sector. Government should take immediate steps for the conservation of ecology and bio-diversity. Environmental Conservation Act of February 1995 along with other policies that are concern about ecology should be modified to conserve the environment and should identify the local and foreign actors who violate rights and livelihood of the marginal people. In addition, government needs to ensure enabling atmosphere for marginal people to access natural resources.

\section{References}

1. Annual Report 2012-13, National Board of revenue.

2. Islam S, Islam M, Rahman T (2006) "Effective renewable energy activities in Bangladesh." Renewable Energy 31: 677-688.

3. Gazette B (2008) Renewable Energy Policy of Bangladesh".

4. Bangladesh Economic Review (2012) Ministry of Finance.

5. Bangladesh Statistical Pocket Book (2012) Bangladesh Bureau of Statistics.

6. Bangladesh Bank.

7. Banglapedia, National Encyclopedia of Bangladesh.

8. http://en.wikipedia.org/wiki/Bangladesh.

9. http://www.powerdivision.gov.bd/index.php?page_i $\% 20 \mathrm{~d}=263$

10. Ministry of Power, Energy and Mineral Resources, Govt. of the People's Republic of Bangladesh, Renewable energy policy of Bangladesh, Dhaka, Bangladesh, Nov. 2008

11. Ministry of Power Energy and natural resources.

12. Ministry of land Bangladesh.

13. Ministry of Fishery and Livestock.

14. Sarkar MAR, Ehsan M, Islam MA (2003) "Issues relating to energy conservation and renewable energy in Bangladesh," Energy for Sustainable Development 7: 77-87.

15. National Bureau of revenue.

16. Power Development Board.

17. Reform in revenue Administration (RIRA) project website.

18. Rahma MS, Saha SK, Habiba U, Chowdhury SM (2013) Present Situation of Renewable Energy in Bangladesh: Renewable Energy Resources Existing in Bangladesh, Global Journal of Researches in Engineering Electrical and Electronics Engineering Volume 13 Issue 5 Version 1.0

19. Water Development Board. 